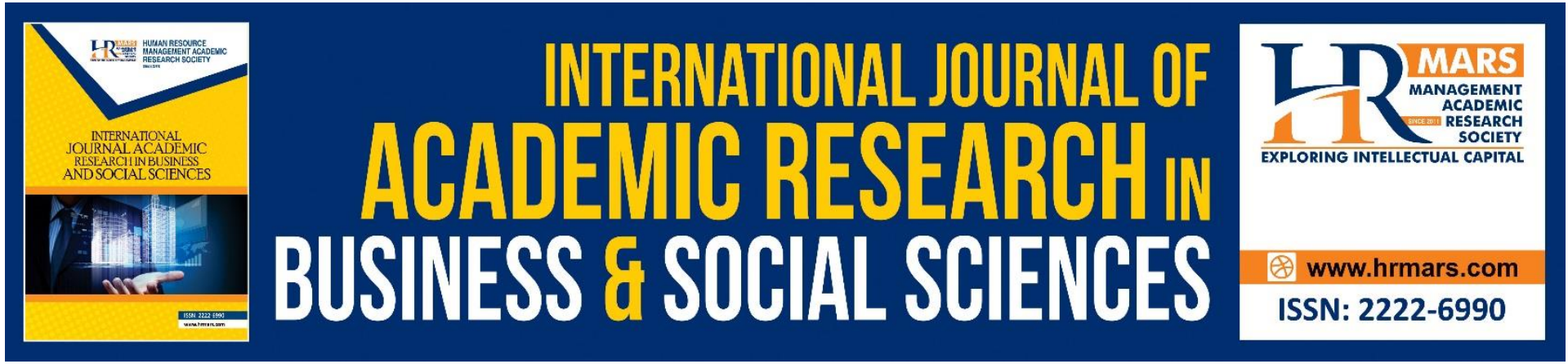

\title{
The Voting Decision: Social Media Use, Internal and External Efficacy Aspects
}

Mohd Sufiean Hassan, Rosilawati Sultan Mohideen, Abd Aziz A'zmi, Siti Nurshahidah Sah Allam, Fazurah Mustaffa, Abdul Rauf Ridzuan

To Link this Article: http://dx.doi.org/10.6007/IJARBSS/v11-i7/10362 DOI:10.6007/IJARBSS/v11-i7/10362

Received: 25 May 2021, Revised: 24 June 2021, Accepted: 11 July 2021

Published Online: 28 July 2021

In-Text Citation: (Hassan et al., 2021)

To Cite this Article: Hassan, M. S., Mohideen, R. S., A'zmi, A. A., Allam, S. N. S., Mustaffa, F., \& Ridzuan, A. R. (2021). The Voting Decision: Social Media Use, Internal and External Efficacy Aspects. International Journal of Academic Research in Business and Social Sciences, 11(7), 1525-1535.

Copyright: (c) 2021 The Author(s)

Published by Human Resource Management Academic Research Society (www.hrmars.com) This article is published under the Creative Commons Attribution (CC BY 4.0) license. Anyone may reproduce, distribute, translate and create derivative works of this article (for both commercial and non-commercial purposes), subject to full attribution to the original publication and authors. The full terms of this license may be seen at: http://creativecommons.org/licences/by/4.0/legalcode

Vol. 11, No. 7, 2021, Pg. 1525 - 1535

Full Terms \& Conditions of access and use can be found at http://hrmars.com/index.php/pages/detail/publication-ethics 


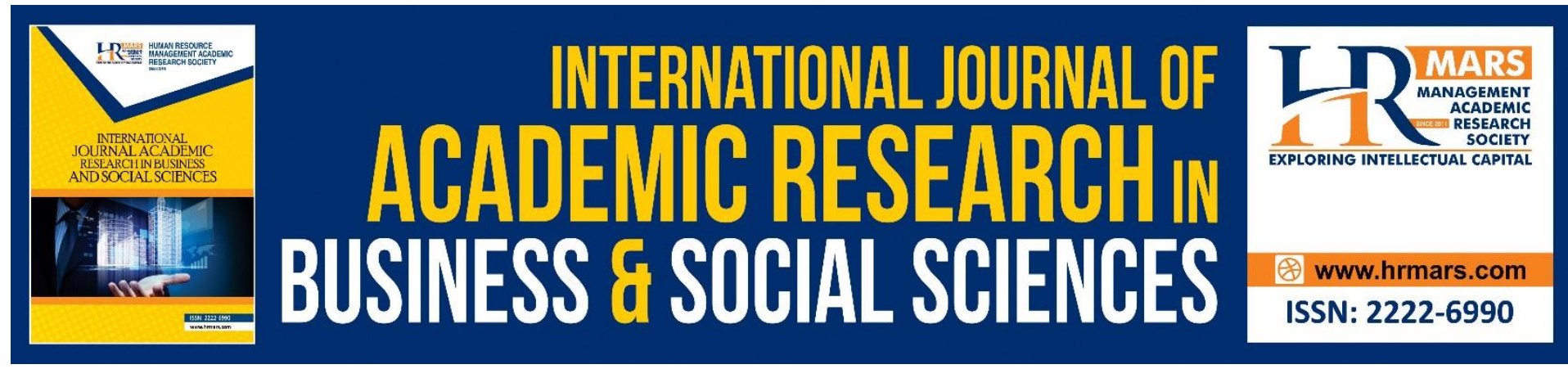

\title{
The Voting Decision: Social Media Use, Internal and External Efficacy Aspects
}

\author{
Mohd Sufiean Hassan ${ }^{1}$, Rosilawati Sultan Mohideen², Abd Aziz \\ $A^{\prime} z \mathrm{mi}^{3}$, Siti Nurshahidah Sah Allam ${ }^{4}$, Fazurah Mustaffa ${ }^{5}$, Abdul \\ Rauf Ridzuan ${ }^{6}$ \\ 1,2,4,6Universiti Teknologi MARA, Melaka Branch, Malaysia, ${ }^{3,5}$ Kolej Universiti Islam Melaka, \\ Malaysia \\ Email: mohdsufiean@uitm.edu.my
}

\begin{abstract}
Malaysia is a country that practices parliamentary democracy and a constitutional monarch. Elections are an integral part of each independent nation's democratic system. Voters have criteria to choose from, as well as the candidate's political stance. The younger generation is defined as a group of people who exhibit political behaviour cultural traits such as being critical, learning more about a subject, and being concerned about transparency and honesty. This study aims to examine the level of the political efficacy of young people on the voting decisions of young people. The quantitative method used questionnaire instruments involving 384 respondents in the Melaka state. The SPSS statistics programme was used to analyse the data. The findings revealed that respondents' social media use is low while political efficacy is moderate. Young people's political efficacy is moderate in both internal and external political efficacy, as measured by understanding political and administrative principles and mastery of local and national political concerns. This research has strengthened the concept of political efficacy, which will have a more mature and rational impact on people's political engagement.
\end{abstract}

Keyword: Social Media Use, Internal Political Efficacy, External Political Efficacy, Young Voter, Democratic System

\section{Introduction}

Elections are an important element in a democratic system for an independent country. It is a process that allows the people to choose the leaders and parties that will form the government. Each time an election takes place, the contesting political party will field the best candidate to ensure that it is the voters' choice. On the other hand, voters have the criteria of the candidate they will choose in addition to the political ideology adhered to by the candidate. Malaysia is a country that practices parliamentary democracy and a constitutional monarch.

Parliamentary democracy in Malaysia stipulates that only legitimate political parties and achieves victory in general elections held every five years will occupy Parliament and run the government through the provisions of the Federal Constitution. A general election is a 
method by which the people's vote is used to select a candidate elected in an election who will fill the legislature and Local Government positions. The younger generation of youth is the largest group today with specific behavioral and cultural characteristics. Their position, role, and involvement in many matters need to be strengthened. The future leadership of the country depends on the young people of today. These people will determine the fall or rise of political parties and leaders in this country. Their involvement and participation in elections are vital to choosing the party that will rule the country.

The post-GE 2018 saw the PH Government enact a law in Parliament to lower the voting age from 21 to 18 and managed to get support from MPs, including from the opposition parties, namely BN and PAS. This raises various polemics in terms of political effectiveness and the willingness of the 18 -year -old to participate in electoral politics. These include their maturity in political decision-making, an increase in the number of voters, the cost of conducting elections, an increase in election management staff as well as logistical suitability, and various other implications that will be faced as a result of the enforcement of the 18 year age limit. Furthermore, this group is an active social media user. Therefore a wide range of information, whether true or false, also influences the political participation of young people.

The decision to lowering the voting age must have an empirical explanation, and even though this notion being discusses, there is no empirical data or model develop from the previous study. Thus, this study aims to examine the level of the political efficacy of young people on the voting decisions of young people.

\section{Social Media Use Boosts New Voter Decision to Vote}

Young people regard the Internet as a flexible medium for information seeking (Kim, 2013) (Rosengard, 2014), get political news update (Ingrid Bachmann 2013), online political messaging for opinion expression (Valenzuela, 2013), and political expression (Masahiro Yamamoto 2014) enhance through a mobile political application.

According to Mohd Sufiean et al (2016) social media help to increase new voter intention to participate in the general election. However, Pinkleton (2012) stresses that greater exposure to negative political issues or dissatisfaction with media can affect participants' cynicism and political apathy will lead to lower political participation among young people. It also will affect to the different levels of political participation either participate or not to participate.

Biswas et al (2014) findings show that social media significantly influences the voting behavior of the people in large and semi-urban areas through the use of social media. Social media plays an important role in the voting behavior of young voters using attractive advertisements, especially towards students. It is not only can attract people's attention even shaping the behavior to turning out during the election. Their study also found that people who actively use social media tend to make their decision based on the political content he reads. Social media not only raises awareness among the public but also serves as a force to demand individual's turnout and vote. YouTube is among the sources of information that decide to vote (Biswas et al., 2014).

According to Bashky et al (2012), social media has a tremendous influence on voter participation in elections. Facebook is found to be a digital platform that has high political sentiment among users. This is due to its function that allows users to comment and share status, audio, and visuals with other users. In addition, they also can interact and participate in the existing public debate space. Besides, Junaidi (2010) stated, the influence of social 
media such as Facebook and Twitter is very large in the context of political behavior among students. One of the understandable political behaviors is the decision to vote during an election. In the 14th general election (GE), the prominence of people's issues such as rising prices of goods and petrol, corruption, nepotism, implementation of GST, and marketability of graduates had an impact on voting behavior in the election (Hamedan et al., 2019).

Chen (2016) stated that today's social media networks can lead to an increase in political participation, among which, is the act of voting in elections. In another study, the level of political participation either through social media or influenced by social media was found to be high among young people especially students (Zainon \& Hashim, 2017). In the United States, the impact of social media on turnout also shows a direct correlation. Social media is found to have a strong impact on citizens who are already interested in politics, so they are more oriented to go out and vote (Steinberg, 2015). Thereby, we propose the following:

\section{Internal Political Efficacy and New Voter Decision to Vote}

Internal political efficacy may have less explanatory value in the prediction of unplanned or habitual behavior, simply due to the more influential role of other motivational forces and automatic activation (Bargh, 1997). Indeed, evidence suggests that intentional behavior can be explained using internal efficacy, also represented as perceived behavioral control (Fishbein \& Ajzen, 1981). Studies on political efficacy in Germany stated that internal political efficacy is something that is translated from political knowledge and then influences various actions of political participation, including conventionally i.e., going out to vote (Reichert, 2016). Internal efficacy is also described by Ajzen (2012) as something that increases the willingness to participate. Such willing behavior is an important basic condition in determining actual action or behavior. This is also in line with the statements of Deth et al (2007) particularly in the context of voting turnout.

Studies in 24 European and American countries (1999-2000) on political efficacy explain the findings of the study based on individuals and countries in general. Individually, internal efficacy plays a major role in driving a person's likelihood of engaging with political participation. In general, at the national level, internal efficacy drives the probability of participation in representative forums, however, it does not directly lead to turnout results. Thus, individual representative participation is determined by internal efficacy, whereas voting exit is seen as a conventional civic norm (Amna et al., 2004).

Schulz (2005) states that voting is one of the political participations which is also referred to as electoral participation. This action is the least intensive political participation compared to other political activities. According to him, electoral participation is related to political interests, knowledge, trust, and political communication. The findings of the study state, internal efficacy is related to political interests, political discussion, and media use. Thus, internal efficacy indirectly contributes to the voting activity which is electoral participation. Reichert (2016) who conducted a study on respondents who lived in Germany aged 16 years and older also found that internal political efficacy did not directly affect the decision to vote, but it had an indirect influence through the conscious decision to vote.

Political internal efficacy is also referred to as political self-efficacy that justifies political engagement, when a person frequently obtains information related to political issues, in turn having an impact on voting behavior. The more a person engages in political engagement, increases their self-efficacy and tend to vote in the future (Tuinhof, 2016). The term self-efficacy was also used in the study by Children of the National Longitudinal Study of 
Youth. The findings of the study explain that self-efficacy has a positive effect on voting behavior among young people who are first-time voters. This relationship also contributes to the turnout in elections especially from low-income families (Condonm \& Holleque, 2013). Moreover, a person with a high level of internal efficacy is said to have low external efficacy, tending to participate conventionally.

\section{External Political Efficacy and New Voter Decision to Vote}

Studies on external efficacy were conducted in New Zealand on non -voters and young non voters. External efficacy is more on the behavior of young people who do not vote. Young people who do not vote in different places have low external efficacy. These groups are not interested in turning out to vote because they are not interested in politics, politics is irrelevant, complex, politicians cannot trust, and voting does not change anything (Sheerin, 2007). Other studies have also shown the existence of relationships that show low external efficacy or the opposite with high internal efficacy show a negative effect on voting turnout actions (Ha et al., 2012).

External efficacy is also associated with studying the relationship between the maturity of the age of democracy in a place and the turnout. The findings of the study explain, the longer the age of democratic maturity in a place, the higher the level of external effectiveness and participation in elections (Novy \& Katrnak, 2015). In general, the level of external efficacy varies based on the age of maturity of an old or new democracy in a place. The findings of this study are in line with studies conducted among students in democratic and post-communist European countries. Levels of external efficacy and expectations for active participation when they are adults were found to be low in Slovenia and Poland. These two countries are post-communist countries whose democratic maturity age is younger than other European countries (Schulz, 2005). Based on the above said reviews of literature, a theoretical framework is proposed (see Figure 1).

\section{Research Methodology}

Data were collected from pre-screened school and university students studying in Melaka, Malaysia who age 16 to 21 and have experience in using social media to get political information, a method of quantitative research employing convenience sampling techniques. Initially, 400 questionnaires were administered, however, a total of 384 unique and usable responses were successfully collected for a response rate of 96 percent. Survey instruments were adapted from the following sources: social media use (Zhang \& Lin, 2014), internal political efficacy and external political efficacy (Sarieva, 2018), and decision to vote (Muhammad \& Hasan, 2016). The questions are using 5 scale which are strongly disagree, disagree, neutral, agree and strongly agree to measure the data. Pilot test was conducted before proceeding to the final data collection to make sure that the reliability and validity of the instrument. Cronbach Alpha's reliability coefficient for all three variables, above 0.70, shows a good internal consistency (Hair et al., 2010). 
Table 1 : Demographic profile of respondents $(n=384)$

\begin{tabular}{lll}
\hline Variable & Frequency & Percentage \\
\hline Age & 24 & 6.3 \\
$16-17$ & 204 & 53.1 \\
$18-19$ & 156 & 40.6 \\
$20-21$ & & \\
Gender & 114 & 29.7 \\
Male & 270 & 70.3 \\
Female & & \\
Level of Education & 4 & 1.0 \\
PMR & 138 & 35.9 \\
SPM & 242 & 63.0 \\
Diploma & & \\
Race & 378 & 98.4 \\
Malay & 2 & .5 \\
Chinese & 4 & 1.0 \\
Indian & - & - \\
Other & & \\
Family Income & 244 & 63.5 \\
B40 (Below RM 3,000) & 114 & 29.7 \\
M40 (Below RM 6,000) & 26 & 6.8 \\
T20 (RM 13,000 and above) & & \\
\hline
\end{tabular}

Table I displays the demographic profile of the respondents. A total of 384 participants were included in the final sample, out of which most of the respondents were female $(70.3$ percent), the remainder (29.7 percent) were male. 6.3 percent of the students, or 24 of them, are between 16-17, 53.1 percent of the students, or 204 of them, are between the age of 1819 , and the remaining 40.6 percent of the student are aged between 20-21 years. Most of the respondents have been educated to college or higher education level: $1.0 \%$ are PMR, 35.9\% are SPM, and $63 \%$ diploma holders. More than $98 \%$ of respondents are Malay. In addition, 63.5 of the respondents were among B40 in terms of family income.

\section{Research Instrument}

The questionnaire consists of 4 parts used as the instrument of this study. Part A consists of general information on demographic variables such as age, gender, level of education, race, and family income. Part B contains social media use scale adapted from Lin \& Zhang (2014). Part B contains of Political Efficacy scale adapted from Sarieva (2018) and Part D is decision to vote adapted from Muhammad \& Hasan (2016). The scale to measure is a well-established scale that has proven its reliability because it is widely used in past studies. After run pre-test and pilot test, reliability Cronbach's Alpha for all social media use dan political efficacy scales - the constructs of Internal Political Efficacy and External Political Efficacy are between 0.891 - 0.901. This scale contains 43 items and is measured using a 5-level interval scale of $1=$ strongly disagree to $5=$ strongly agree. This measurement scale measures Social media use, Political efficacy and Decision to vote. 
Table 2 : Validity and Reliability

\begin{tabular}{|c|c|}
\hline Code & $\begin{array}{l}\text { Cronbach's } \\
\text { Alpha }\end{array}$ \\
\hline MS1 & I read hard news via social media. \\
\hline MS2 & I repost photos or videos clips on government or politics. \\
\hline MS3 & $\begin{array}{l}\text { I upload photos or videos shot by yourself on non-recreational latest } \\
\text { events. }\end{array}$ \\
\hline MS4 & I vote online. \\
\hline MS5 & $\begin{array}{l}\text { I write blogs on government or politics, such as politics, economics, or } \\
\text { international relations. }\end{array}$ \\
\hline MS6 & I join topic discussions of politics via social media. \\
\hline MS7 & I post political issues on social media and seek help or discussion. \\
\hline MS8 & $\begin{array}{l}\text { I express opinions explicitly on government and politics via social } \\
\text { media. }\end{array}$ \\
\hline MS9 & $\begin{array}{l}\text { I follow and interact with official social media accounts of } \\
\text { governmental or political institutions. }\end{array}$ \\
\hline MS10 & I organize non-governmental campaigns or activities via social media. .898 \\
\hline EPP1 & I can influence the enactment of new laws and political decisions. \\
\hline EPP2 & I can facilitate the election of a political leader whose views I share. $\quad .895$ \\
\hline EPP3 & I can demand that existing laws and political decisions be observed. $\quad .895$ \\
\hline EPK1 & $\begin{array}{l}\text { Together citizens of my country can influence the enactment of new } \\
\text { laws and political decisions. }\end{array}$ \\
\hline EPK2 & $\begin{array}{l}\text { Together citizens of my country can facilitate the election of a political } \\
\text { leader whose views they share. }\end{array}$ \\
\hline EPK3 & $\begin{array}{l}\text { Together citizens of my country can demand that existing laws and } \\
\text { political decisions be observed. }\end{array}$ \\
\hline EPL1 & $\begin{array}{l}\text { The people in charge of government are willing to provide information } \\
\text { on how political decisions are made. }\end{array}$ \\
\hline EPL2 & $\begin{array}{l}\text { The people in charge of government are interested in ensuring equal } \\
\text { rights for all political parties and groups. }\end{array}$ \\
\hline EPL3 & $\begin{array}{l}\text { The people in charge of government are interested in carrying out the } \\
\text { lawful demands of the citizens. }\end{array}$ \\
\hline SM1 & Vote is basic right \\
\hline SM2 & Vote is way of opinion \\
\hline SM3 & Vote is responsibility \\
\hline SM4 & Vote is national duty \\
\hline SM5 & Vote bring change \\
\hline SM6 & Vote brings real representative \\
\hline IPC1 & Political party of candidate \\
\hline IPC2 & Manifesto of the political party/candidate \\
\hline IPC3 & Sign of candidate \\
\hline IPC4 & Political background of the candidate \\
\hline IPC5 & Educational background of candidate \\
\hline IPC6 & Election campaign of candidate \\
\hline PEC1 & Gender of candidate \\
\hline PEC2 & Religion of candidate \\
\hline PEC3 & Race of candidate \\
\hline
\end{tabular}


PEC4 Socioeconomic status of candidate .896

MP1 Economic help given by candidate

.893

MP2 Personal work done by candidate to voter

MP3 Parents decision $\quad .900$

MP4 Decision oneself $\quad .892$

PP1 Integrity of candidate $\quad .892$

PP2 Progressive work of candidate $\quad .891$

PP3 Education of candidate $\quad .893$

PP4 Political experience of candidate $\quad .892$

\section{Findings}

Table 3 shows how the five-point Likert scale is divided into mean level scales. The five-point Likert scale consists of scores 1 to 5 . To calculate the interval difference to obtain the mean which is break into three categories namely low, medium, and high mean, then score 5 is subtracted by a score of 1 and divided by 5 . Therefore, the interval for each mean is between 1.33. The low mean level is at 1.00 to 2.33 , the moderate mean level is in the range of 2.34 to 3.67 , while the high mean level is at 3.67 to 5.00 as in table 3 below.

Table 3. Mean score range

\begin{tabular}{ll}
\hline Mean & Level \\
\hline 1.00 to 2.33 & Low \\
2.34 to 3.67 & Moderate \\
3.68 to 5.00 & High \\
\hline
\end{tabular}

Table 4 shows that the level of students' social media use by education level. It is found that the mean for each education level is slightly different between 1.75 to 2.27 . Furthermore, the descriptive analysis also found that the percentage of education level respondents who scored high was very small with the highest is SPM (4.3\%) followed by Diploma $(4.1 \%)$ and PMR $(0.00 \%)$. Based on the classification of the mean score range, table 4 showed that the overall mean value of the level of students' social media use is 2.16 (SD $=0.68$ ), which is at the level of low social media use.

Table 4. The Level of Social Media Use toward Decision to vote $(n=384)$

\begin{tabular}{llll}
\hline Education/ level & PMR & SPM & $\begin{array}{l}\text { Diploma } \\
(n=242) \\
(n=4)\end{array}$ \\
$\%$ & $\begin{array}{l}(n=138) \\
\%\end{array}$ & $\%$ \\
\hline Low & 100 & 56.6 & 77.7 \\
Moderate & 0 & 39.1 & 18.2 \\
High & 0 & 4.3 & 4.1 \\
Mean & 1.75 & 2.27 & 2.09 \\
\hline
\end{tabular}

$P M R=$ Peperiksaan Menengah rendah, SPM= Sijil Pelajaran Malaysia

Mean=2.16; $S D=0.68$

From the Table 5, the level of students' Internal Political Efficacy in Decision to Vote is moderate (Mean $=2.58$ ) with a range mean by education level from $2.41(P M R)$ to $2.70(S P M)$. When examined in terms of the percentage of distribution at high level, SPM is the higher (10.2\%) follow by Diploma (9.9\%) and PMR (0.00\%). 
Table 5. The Level of Internal Political Efficacy toward Decision to vote $(n=384)$

\begin{tabular}{llll}
\hline Education/ level & PMR & SPM & $\begin{array}{l}\text { Diploma } \\
(n=4)\end{array}$ \\
& $\%$ & $\begin{array}{l}(n=138) \\
\%\end{array}$ & $\%$ \\
\hline Low & 50 & 33.3 & 43.8 \\
Moderate & 50 & 56.5 & 46.3 \\
High & 0 & 10.2 & 9.9 \\
Mean & 2.41 & 2.70 & 2.51 \\
\hline
\end{tabular}

$P M R=$ Peperiksaan Menengah rendah, SPM= Sijil Pelajaran Malaysia

Mean $=2.58 ; S D=0.80$

From the Table 6 , this study found that the level of external political efficacy among education level is at moderate level (Mean=2.92) with a range mean by level of education from 2.83 (PMR) to 2.93 (SPM). It means that all respondents have moderate level of external efficacy. In addition, those with high level of external political efficacy show that all level of education has a low percentage of $17.4 \%$ (SPM) to $21.5 \%$ (Diploma).

Table 6. The Level of External Political Efficacy toward Decision to vote ( $n=384)$

\begin{tabular}{|c|c|c|c|}
\hline Education/ level & $\begin{array}{l}\text { PMR } \\
(n=4) \\
\% \\
\end{array}$ & $\begin{array}{l}\text { SPM } \\
(n=138) \\
\%\end{array}$ & $\begin{array}{l}\text { Diploma } \\
(n=242) \\
\%\end{array}$ \\
\hline Low & 0 & 33.3 & 40.5 \\
\hline Moderate & 100 & 49.3 & 38 \\
\hline High & 0 & 17.4 & 21.5 \\
\hline Mean & 2.83 & 2.93 & 2.92 \\
\hline
\end{tabular}

$P M R=$ Peperiksaan Menengah rendah, $S P M=$ Sijil Pelajaran Malaysia

Mean= 2.92; $S D=1.02$

\section{Discussion and Conclusion}

This study was conducted to measure the level of new voter social media use and political efficacy towards voting. From the data, we found that new voters in Melaka are possessed low social media use. Internal efficacy and external political efficacy also at a moderate level. Most of them are students and are exposed to school or institution syllabus such as Nationalism, civic and moral, and other subjects relating to the democratic system. Based on this study, greater exposure to negative political issues or dissatisfaction with social media can affect participants' cynicism, and political apathy will lead to lower political participation among new voters. It shows that social media is not the only medium for the respondent to searching political information. So, in order to prepared Malaysian voters with real knowledge of political participation, the various medium must be employed.

Propagating young people with negative political issues would affect the tendency of new young voters to perform their votes during elections. To win over new young voters, politicians and political parties in Malaysia should play an essential role in cultivating positivism in politics to encourage new young voters to vote. Even though the government has decided to lower the voting age from 21 to 16 years old, education about politics is still necessary to nurture new young voters on the importance of their voting decision. This study contributes to a better understanding of political communication knowledge by highlighting social media usage, internal political efficacy, and external political efficacy in understanding 
the determinants of new voter decision-making. This study also provides empirical insight into the understanding of voting decisions among new young voters influenced by social media use, internal political efficacy, and external political efficacy.

\section{Corresponding Author}

Dr. Mohd Sufiean Hassan, Faculty of Communication and Media Studies, Universiti Teknologi MARA, Melaka Branch, Malaysia. Email: mohdsufiean@uitm.edu.my

\section{Acknowledgement}

The authors would like to thank the Universiti Teknologi MARA, Melaka Branch, Malaysia for the funding received under the Internal TEJA Grant 2021 (GDT2021/1-1) to support this study.

\section{References}

Ajzen, I. (2012). Martin Fishbein's legacy: The reasoned action approach. The Annals of the American Academy of Political, 11-27.

Ali, S., Safar, M. H., Salman, A., Hasim, M. S., Baru, M., \& Landskap, P. (2011). New media and democracy : The changing political landscape in Malaysia. Akademika, 81(1), 15-21.

Amna, E., Munck, I., \& Zetterberg, P. (2004). Meaningful Participation? Political Efficacy of Adolescent in 24 Countries. Sweden.

Bashky, E., Rosenn, I., \& Marlow, C. (2012). The role of social networks in information diffusion. Proceedings of the 21st International Conference on World Wide Web, (pp. 519528).

Biswas, A., Ingle, N., \& Roy, M. (2014). Influence of social media on voting behaviour. Journal of Power, Politics and Governance, 127-155.

Chen, J. (2016). Can online social networks foster young adults' civic engagement?. Telematics and Informatics, 487-497.

Condonm, M., \& Holleque, M. (2013). Entering politics: General self effication and voting behaviour among young people. Political Psychology, 112-125.

Deth, J. V., Montero, J. R., \& Westholm, A. (2007). Citizenship and involvement in European democracies: A comparative. London: Routledge.

Ha, L., Wang, F., Fang, L., Yang, C., Hu, X., Yang, L., \& Xu, Y. (2012). Political efficacy and the use of local and national news media among undecided voters in a swing state: A study of general population voters and first-time college student voters. School of Media and Political Communication, 1-29.

Hair, J. F., Black, W. C., Babin, B. J., \& Anderson, R. E. (2014). Multivariate Data Analysis. Pearson Education Limited.

Hamedan, N. N., Alsagoff, S. A., \& Ghazali, A. H. (2019). Media, isu dan tingkah laku pengundi dalam pilihan raya umum ke-14: satu kajian awal. Journal of Communication, 293-312.

Junaidi, A. (2010). Trend pengundian etnik melayu dan cina/tioghoa dalam pilihan raya 20092011 di malaysia. Bangi : Institut Kajian Etnik (KITA) UKM.

Hassan, M. S., Allam, S. N., Azni, M. Z., \& Khamis, H. (2016). Social media and political participation among young people. Jurnal Sains Sosial, 1(1), 95-114.

Muhammad, H. J., \& Hasan, S. S. (2016). Development of the decision to vote scale. Pakistan Journal of Social and Clinical Psychology, 14(2), 10-14.

Novy, M., \& Katrnak, T. (2015). Democratic Maturity, External Efficacy and Participation in Election: Towards macro-micro Interaction. Austrian Journal of Political Science, 1-20. 
Philip H, P. I. (1983). The participatory consequences of internal and external political efficacy: A research note. The Western Political Quarterly, 400-409.

Reichert, F. (2016). How internal political efficacy translates political knowledge into political participation: Evidence from Germany. Europe's Journal of Psychology, 12(2), 221-241. https://doi.org/10.5964/ejop.v12i2.1095

Sarieva, I. (2018). How to Measure Perceived Political Efficacy? A Three-Component Scale. Psychology, Journal of the Higher School of Economics, 15(3), 477-490. https://doi.org/10.17323/1813-8918-2018-3-477-490

Schulz, W. (2005). Political efficacy and expected political participation among lower and upper. Melbourne: Australian Council for Educational Research.

Steinberg, A. (2015). Exploring web 2.0 political engagement: Is new technology reducing the biases of political participation?. Electoral Studies, 102 $=116$.

Zainon, N., \& Hashim, R. (2017). Political voice of young Malaysians: Online political participation among university students. International Journal of Academic Research in Business and Social Sciences, 649-654.

Zhang, X., \& Lin, W.-Y. Y. (2014). Political participation in an unlikely place: How individuals engage in politics through social networking sites in China. International Journal of Communication, 8(1), 22. http://ijoc.org/index.php/ijoc/article/view/2003 